\title{
Predicting Strata Temperature Distribution from Drilling Fluid Temperature
}

\author{
Shiguang $\mathrm{Xu}{ }^{1,2}$, Junjie $\mathrm{Ba}^{1}$, Xianfeng Chen ${ }^{3}$, Ting Zheng ${ }^{4}$,Yaochi Yang ${ }^{5}$ and Liang Guo ${ }^{6}$ \\ ${ }^{1}$ Faculty of Land Resource Engineering, Kunming University of Science and Technology, \\ Kunming 650093, China \\ ${ }^{2}$ Yunnan Geologic and Mineral Bureau of Exploration \& Exploitation, Kunming 650051, China \\ ${ }^{3}$ Yunnan Lan and Resources Vocational College, Kunming 652501, China \\ ${ }^{4}$ Kunming Prospecting Design Institute of China Nonferrous Metals Industry, \\ Kunming 650011, China \\ ${ }^{5}$ Yunnan Tonghui Resource Exploration Company(Ltd), Kunming 650100, China \\ ${ }^{6}$ Yunnan Geotechnical Engineering Investigation Design Research Institute, \\ Kunming 650051, China
}

Email: bajunjie@kmust.edu.cn

\begin{abstract}
Geothermal gradient is one of the most important parameters for geothermal exploration and exploitation. Mud is generally used as a drilling fluid in geothermal wells. According to energy conservation law, when the drilling penetrates through an aquifuge or aquitard, its temperature can be used to establish the mathematical analysis model for estimating the geothermal gradient. The recorded mud temperatures in some practical drilling cases in southwest China have been applied to study the influence radius of geotherm that is conducted by surrounding rock into the derived formula. The fitting calculation results show that the absolute error is generally very low, being less than $10 \%$, which indicates that the proposed formula can be used to effectively predict the geothermal gradient. The calculation indicates that it is only when the rock conductive influencing radius is very small (around $0.25 \mathrm{~m}$ ) that it is possible to have a reasonable solution.
\end{abstract}

Keywords: Drilling fluid of mud, Geothermal gradient, Temperature, Energy conservation law, Rock conductive influencing radius.

\section{INTRODUCTION}

Geothermal resource is one of the newest sources of energy. It has recently gained considerable attention due to its renewable and clean characteristics. For the sake of energy conservation and to address the energy shortage, the exploitation and utilization of geothermal resources is becoming increasingly important, which leads to the reasonable utilization of geothermal resources to be an important strategic action that can alleviate the problems of resources shortages and environmental degradation [1-4].

Since geothermal energy has great potential for development and broad prospects for use, the realization of geothermal resources for sustainable development and utilization is a critical issue for the world's geothermal industry [5-14]. Scholars all over the world have done much research on the geothermal resources and hot springs, including studies on heat flow, the thermal state of the rock, the thermal structure of the Earth's crust or upper mantle, the geothermal effects and climate change, mining geotherm, and other geothermal resources. [15-19]. Strata temperature, which is difficult to measure directly, is a key parameter in the research and development of underground hot water, the thermal storage to divide the drilling depth in the geothermal system, and the evaluation of the potential of geothermal resources. Currently, the geothermal temperature scale approach is an economical and effective means of providing this parameter. This approach has been widely used in estimating reservoir temperatures, including cationic, silica, gas chemistry, isotope, and so on [19-30].

The drilling fluid of mud, which can interfere with the temperature field near the borehole during the drilling process, is generally used in exploration and development of geothermal wells. When the drilling time is long enough to make the temperature balance with the surrounding rock, the surface temperature can reflect the actual status of the stratum temperature. Some related work has been done by Lachenbruch and Hrewer (1959), Albright (1976), Barelli and Palama (1981), and so on [31-37].

Geothermal gradient is one of the most important parameters for geothermal exploration and exploitation. In the drilling process, the effect of exchanging heat between the drilling fluid, which mainly consists of drilling mud, and the strata that surround the borehole will result in a distinct temperature increase in the circulated outflow fluid. If drilling penetrates through aquifuge or aquitard with a certain 
thickness, the drilling fluid will have almost no leakage, and the heat attracted from the surrounded strata will be mainly supplied by conduction. For a relatively constant fluid flowrate $Q_{l}$, the geothermal gradient can be calculated by energy conservation, and the reservoir temperature can be estimated resulting in a more reasonable drilling program being put forward.

\section{DERIVATION OF THE CALCULATING EQUATION}

The physical model of calculation is shown in Fig.1. When a borehole is drilled at a depth of $H_{w}$, for the given temperature of the inflow $\left(T_{0}\right)$ and outflow drilling fluid $\left(T_{n}\right)$, if the depth is divided into $n$ parts evenly, the thickness of each part is:

$\mathrm{z}=H_{w} / n$

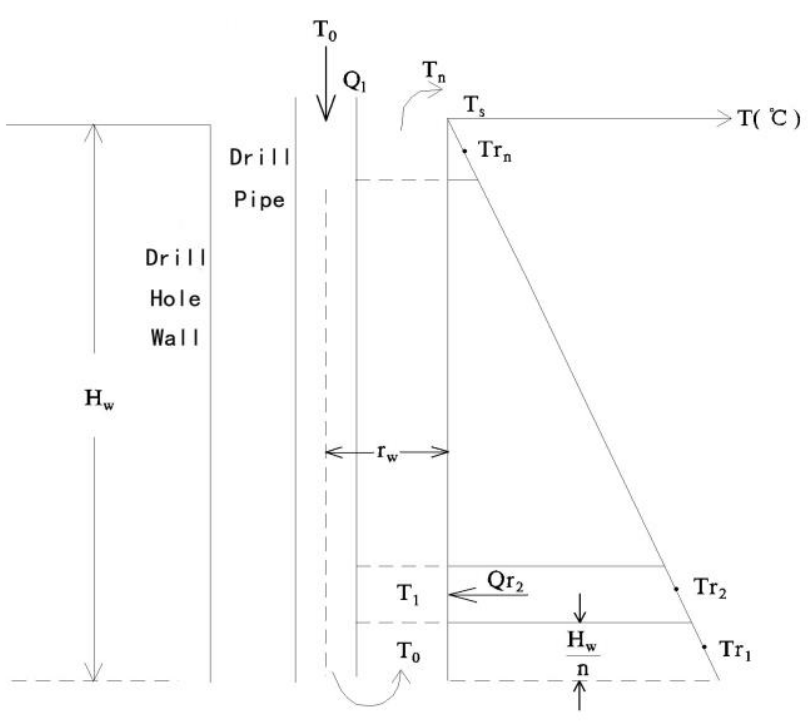

Figure 1. Model of drilling fluid temperature prediction of the reservoir temperature

Fig. 1 shows that the rising temperature in each part is obviously caused by the heat absorbed from the preceding part of the surrounding rock:

$$
\left\{\begin{array}{l}
C_{l}\left(T_{1}-T_{0}\right) \rho_{l} Q_{l}=Q_{r 1} \\
C_{l}\left(T_{2}-T_{1}\right) \rho_{l} Q_{l}=Q_{r 2} \\
C_{l}\left(T_{3}-T_{2}\right) \rho_{l} Q_{l}=Q_{r 3} \\
\ldots \ldots \ldots \ldots \ldots \ldots \ldots \ldots \ldots \ldots \ldots \ldots \\
C_{l}\left(T_{n}-T_{n-1}\right) \rho_{l} Q_{l}=Q_{r n}
\end{array}\right.
$$

where $C_{l}$ specific heat of the drilling fluid, $K J /\left(K g \cdot{ }^{\circ} \mathrm{C}\right)$; $\rho_{l}$ - density of the drilling fluid, $K g / \mathrm{m}^{3} ; Q_{l}$ — constant fluid flowrate, $\mathrm{m}^{3} / \mathrm{s} ; Q_{r l}, Q_{r 2}, Q_{r 3} \ldots Q_{r n}$ conductive heat flow from surrounding strata in different depth (upwards from bottom of borehole) $(\mathrm{KJ} / \mathrm{s})$;

$T_{0}, T_{1}, T_{2}, \ldots \ldots T_{n-1}$ temperature of the drilling fluid corresponding to the divided depth $\left({ }^{\circ} \mathrm{C}\right)$.

According to the conductive equation, the heat flow that comes into the borehole from radial surrounding strata for a given divided depth can be described as:
$Q_{r i}=-K_{r}(2 \pi r \Delta z) \frac{d T}{d r}, i=1,2,3 \ldots \ldots n$

where $K_{r}-$ surrounded rock conductivity, $W /(m \cdot k) ; r$ the maximum distance that will cause heat flow from the surrounded strata while drilling, $m ; \frac{d T}{d r} \_$horizontal radial geothermal gradient at a given depth, ${ }^{\circ} \mathrm{C} / m ; 2 \pi r \Delta z$ - the heat exchanging area between the drilling fluid and the surrounding strata at a given depth, $m^{2}$.

If the variable is separated and the integral transformation is used on equation (3) [38-39], the heat flow occurring at depth $i$ can be derived as:

$Q_{r i}=\frac{2 \pi r_{w} K_{r}\left(T_{r i}-T_{i-1}\right)}{\ln \frac{R_{i}}{r_{w}}} \Delta z, \quad i=1,2,3 \ldots \ldots n$

where $T_{r i}$ rock temperature of the divided depth $i,{ }^{\circ} \mathrm{C}$; $r_{w}$-borehole radius, $m ; R_{i}$ rock conductive influencing radius of the divided depth $i, m$;

Combining equation (4) in equation (2) yields the following:

$1000 C_{l}\left(T_{i}-T_{i-1}\right) \rho_{l} Q_{l}=Q_{r i}=\frac{2 \pi r_{w} K_{r}\left(T_{r i}-T_{i-1}\right)}{\ln \frac{R_{i}}{r_{w}}} \Delta z$

Or:

$\frac{1000 C_{l} \rho_{l} Q_{l}}{2 \pi r_{w} K_{r}} \ln \frac{R_{i}}{r_{w}} \frac{T_{i}-T_{i-1}}{\Delta z}=T_{r i}-T_{i-1}$

Equation (6) is high non-linear and remains hard to solve. However, when the drilling depths are divided into enough sections evenly, the thickness of each section is very small. The heat transfer in the upper and lower sections of the surrounding rock is approximately equal in scope, and the $\frac{R_{i}}{r}$

$r_{w}$ could be considered as a constant.

In this case, the following applies:

$b=\frac{1000 C_{l} \rho_{l} Q_{l}}{2 \pi r_{w} K_{r}} \ln \frac{R_{i}}{r_{w}}$

This parameter has length dimension. Thus, the equation (7) can be simplified as:

$b \frac{T_{i}-T_{i-1}}{\Delta z}=T_{r i}-T_{i-1}$

Take the temperature of drilling fluid with the depth as function $\mathrm{T}(\mathrm{z})$ (Coordinate of $\mathrm{Z}$ is positive downwards from the ground), and the surrounding rock temperature function as $\operatorname{Tr}(\mathrm{z})$, then equation (8) can be expressed as a differential equation:

$-b \frac{d T}{d z}=T_{r}-T$ 
Considering that geothermal growth is linear in the aquifuge, the gradient is fixed, as expressed by the following:

$G(t)=\frac{\left(T_{r i}-T_{r i+1}\right) n}{H_{w}} \quad i=1,2,3 \ldots \ldots . n-1$

Or:

$T_{r}=T_{s}+G(t) z$

$\mathrm{G}(\mathrm{t})$ is simplified as $\mathrm{G}$. Combining equation (11) and equation (9) yields the following:

$-b \frac{d T}{d z}=T_{s}+G z-T$

Its general solution is:

$T=b G+\left(T_{s}+G z\right)-C_{0} e^{z / b}$

where $C_{0}$ is an undetermined constant. Making use of the surface temperature condition:

$T(z=0)=T_{n}=b G+T_{s}-C_{0}$

Hence,

$C_{0}=b G+T_{s}-T_{n}$

Then, we have:
$T(z)=b G+\left(T_{s}+G z\right)-\left(T_{s}+b G-T_{n}\right) e^{z / b}$

To determine the geothermal gradient $G$, the bottom hole temperature $T_{0}$ is inserted into equation (16), yielding the following:

$T\left(z=H_{w}\right)=T_{0}=b G+\left(T_{s}+G H_{w}\right)-\left(T_{s}+b G-T_{n}\right) e^{H_{w} / b}$

Namely, equation (17)can be changed to:

$G=\frac{T_{s}+\left(T_{n}-T_{s}\right) \exp \left(H_{w} / b\right)-T_{0}}{b \exp \left(H_{w} / b\right)-\left(b+H_{w}\right)}$

Integral constants can also be obtained by the bottom hole temperature $T_{0}$.

Note that we define:

$C_{0}=\frac{b G+T_{s}+G H_{w}-T_{0}}{\exp \left(H_{w} / b\right)}$

Yielding:

$T(z)=b G+\left(T_{s}+G z\right)-\left(T_{s}+b G+G H_{w}-T_{0}\right) e^{\left(z-H_{w}\right) / b}$

Moreover, the above equation can be rewritten as:

$T(z=0)=b G+T_{s}-\left(T_{s}+b G+G H_{w}-T_{0}\right) e^{-H_{w} / b}$

The equation (16) and equation (20) are equivalent.

Table 1. The best-fit list for predicting geothermal gradient through the actual drilling mud

\begin{tabular}{|c|c|c|c|c|c|c|c|c|c|c|c|c|c|}
\hline Arguments & $T_{0}$ & $T_{s}$ & $T_{n}$ & $\begin{array}{l}\rho_{l} \\
\left(K g / m^{3}\right)\end{array}$ & $\begin{array}{l}Q_{l} \\
(l / s)\end{array}$ & $\begin{array}{l}C_{l} \\
K J /\left(K g \cdot{ }^{0} \mathrm{C}\right)\end{array}$ & $r_{w}$ & $H_{w}$ & $R_{i}$ & \multirow[t]{2}{*}{$\begin{array}{l}K_{r} \\
W /(m \cdot k)\end{array}$} & $\begin{array}{l}\text { Calcul } \\
\text { ation } \\
G(t)\end{array}$ & $\begin{array}{l}\text { Actual } \\
\text { measu } \\
\text { rement } \\
G(t) \\
\end{array}$ & \multirow[t]{2}{*}{$\begin{array}{l}\text { Relative } \\
\text { error } \\
(\%)\end{array}$} \\
\hline Hole location & \multicolumn{3}{|c|}{$\left({ }^{\circ} \mathrm{C}\right)$} & & & & \multicolumn{3}{|l|}{$(m)$} & & \multicolumn{2}{|l|}{$\left({ }^{\circ} \mathrm{C} / \mathrm{m}\right)$} & \\
\hline $\begin{array}{l}\text { Yunnan elderly } \\
\text { activity center }\end{array}$ & 23 & 17 & 31 & 1190 & 3.00 & 4.25 & 0.088 & 1382 & 0.25 & 2.4 & 0.030 & 0.028 & 7.14 \\
\hline $\begin{array}{l}\text { Yunnan Tuodong } \\
\text { sports center }\end{array}$ & 22 & 17 & 31 & 1150 & 2.50 & 4.25 & 0.08 & 1285 & 0.25 & 2.4 & 0.034 & 0.033 & 3.03 \\
\hline $\begin{array}{l}\text { Yunnan Yiliang } \\
\text { city coal mining } \\
\text { administration }\end{array}$ & 20 & 17 & 23 & 1200 & 2.50 & 4.12 & 0.108 & 420 & 0.23 & 2.1 & 0.051 & 0.050 & 2.00 \\
\hline $\begin{array}{l}\text { Kunming Lin } \\
\text { Yuan real estate } \\
\text { company }\end{array}$ & 23 & 17 & 30 & 1100 & 2.50 & 4.25 & 0.108 & 801 & 0.25 & 2.8 & 0.049 & 0.045 & 8.89 \\
\hline $\begin{array}{l}\text { Yunnan Xuanwei } \\
\text { hot well }\end{array}$ & 20 & 18 & 26 & 1070 & 2.50 & 4.25 & 0.108 & 1311 & 0.26 & 2.1 & 0.019 & 0.018 & 5.56 \\
\hline $\begin{array}{l}\text { Yunnan Xundian } \\
\text { County Beidaying } \\
\text { pastures }\end{array}$ & 22 & 17 & 24 & 1200 & 1.88 & 4.12 & 0.108 & 692 & 0.25 & 2.8 & 0.028 & 0.023 & 21.74 \\
\hline $\begin{array}{l}\text { Guiyang } \\
\text { Wudang District } \\
\text { xiangzhigou } \\
\text { scenic area }\end{array}$ & 19 & 17 & 24 & 1200 & 2.50 & 4.12 & 0.076 & 1150 & 0.24 & 1.8 & 0.021 & 0.021 & 0 \\
\hline $\begin{array}{l}\text { Kunming } \\
\text { Haigeng sports } \\
\text { training base }\end{array}$ & 23 & 17 & 30 & 1150 & 2.00 & 4.26 & 0.108 & 720 & 0.25 & 2.5 & 0.055 & 0.051 & 7.20 \\
\hline
\end{tabular}




\section{PRACTICAL CASES}

The mud temperatures in some actual drilling cases in southwest China were recorded to study the influence radius of geotherm that is conducted by surrounding rock. By using Excel spreadsheets, the related parameters from these boreholes have been input into the corresponding column, and comprehensive parameters (b) have been calculated according to equation (7). For each borehole, when different values for the influence radius of the surrounding rock's thermal conductivity in each well were given, the corresponding geothermal gradient $G_{i}$ was calculated based on equation (19). By comparing the geothermal gradient value that was calculated with the actual measured temperature in each borehole, the best fitting data (Table 1) were determined. Since the friction heat generated during the drilling process is ignored in the formula derivation of the geothermal gradient, all the calculated values of geothermal gradient appear higher than the actual ones. Furthermore, the simulation is available only when the rock conductive influencing radius is very small (about $0.25 \mathrm{~m}$ ). This indicates that to form a stable heat flow field, the role of the surrounding rock in supplying heat for drilling mud is not essential. The simulation results show that the absolute error rate is generally low in the mass, and the relative error rate is less than $10 \%$.

Setting $0.25 \mathrm{~m}$ of the surrounding rock conductive influencing radius as the empirical value, we can predict the computation in the process of several drilling construction sites in Yunnan and Guizhou Provinces, in southwest China. Comparing the calculated value with the actual detected data of the final hole, the relative error rate is less than $10 \%$ (Table 2), which proves the derived formula is very practical.

Table 2. Comparison of the predicting geothermal gradient through several drilling mud sites in Yunnan and Guizhou Provinces with the actual measured value

\begin{tabular}{|c|c|c|c|c|c|c|c|c|c|c|c|c|}
\hline Arguments & $T_{0}$ & $T_{s}$ & $T_{n}$ & \multirow[t]{2}{*}{$\begin{array}{l}\rho_{l} \\
\left(K g / m^{3}\right)\end{array}$} & \multirow[t]{2}{*}{$\begin{array}{l}Q_{l} \\
(l / s)\end{array}$} & \multirow[t]{2}{*}{$\begin{array}{l}C_{l} \\
K J /\left(K g \cdot{ }^{o} C\right)\end{array}$} & \multirow[t]{2}{*}{$\begin{array}{l}r_{w} \\
(m)\end{array}$} & \multirow[t]{2}{*}{$\begin{array}{l}H_{w} \\
(m)\end{array}$} & \multirow[t]{2}{*}{$\begin{array}{l}K_{r} \\
W /(m \cdot k)\end{array}$} & $\begin{array}{l}\text { Calculat } \\
\text { ion } \\
G(t) \\
\end{array}$ & $\begin{array}{l}\text { Actual } \\
\text { measurement } \\
G(t)\end{array}$ & \multirow[t]{2}{*}{$\begin{array}{l}\text { Relative } \\
\text { error } \\
(\%)\end{array}$} \\
\hline Hole location & \multicolumn{3}{|c|}{$\left({ }^{0} \mathrm{C}\right)$} & & & & & & & \multicolumn{2}{|l|}{$\left({ }^{\circ} \mathrm{C} / \mathrm{m}\right)$} & \\
\hline $\begin{array}{l}\text { Guizhou Pingba } \\
\text { County Xujiadu }\end{array}$ & 22 & 17 & 21 & 1200 & 2.00 & 4.12 & 0.108 & 400 & 1.3 & 0.0103 & 0.0105 & 1.91 \\
\hline $\begin{array}{l}\text { Yunnan Dali city } \\
\text { haidong hot well }\end{array}$ & 20 & 17 & 21 & 1180 & 1.67 & 4.26 & 0.076 & 760 & 2.4 & 0.0145 & 0.0135 & 6.89 \\
\hline $\begin{array}{l}\text { Kunming New } \\
\text { Asia sports city }\end{array}$ & 21 & 17 & 25 & 1100 & 3.00 & 4.425 & 0.108 & 773 & 2.5 & 0.031 & 0.030 & 3.33 \\
\hline $\begin{array}{l}\text { Yunnan Luoping } \\
\text { county people's } \\
\text { hospital }\end{array}$ & 20 & 17 & 21 & 1180 & 2.00 & 4.26 & 0.076 & 860 & 1.8 & 0.0129 & 0.0124 & 3.88 \\
\hline $\begin{array}{l}\text { Yunnan Yuxi } \\
\text { cigarette factories } \\
\text { filter rods factory }\end{array}$ & 19 & 17 & 23 & 1180 & 2.00 & 4.12 & 0.108 & 660 & 1.9 & 0.0305 & 0.0279 & 8.52 \\
\hline
\end{tabular}

\section{CONCLUSIONS}

(1) In the process of geothermal exploration, the drilling fluid of mud will extract heat from the surrounding rock when penetrating through aquifuge, which will inevitably result in a significant temperature increase in the outflow drilling fluid. Since the heat thoroughly transfers by conduction, Fourier law and energy conservation law can be employed to calculate the strata temperature.

(2) Once the parameters of the drilling mud fluid and the rock thermal conductivity are measured, the general derived formula $G=\frac{T_{s}+\left(T_{n}-T_{s}\right) \exp \left(H_{w} / b\right)-T_{0}}{b \exp \left(H_{w} / b\right)-\left(b+H_{w}\right)}$ can be used to estimate the geothermal gradient in the aquifuge.

(3) The fitting calculation results of the thermal influence radius, which is conducted and formed by surrounding rock, show that the relative error rate is less than $10 \%$ in some practical drilling cases in southwest China.

(4) Only when the rock conductive influencing radius is very small, it is possible to have a reasonable solution, which indicates that the role of the surrounding rock in supplying heat for drilling mud is not essential to form a stable state. The suggested value is around $0.25 \mathrm{~m}$ empirically.

\section{REFERENCES}

[1] Guo, Q. H., "Hydrogeochemistry of high-temperature geothermal systems in China: A review," Applied Geochemistry, vol. 27, no. 10, pp. 1887-1898, 2012. DOI: $10.1016 /$ j.apgeochem.2012.07.006

[2] Guo, S. Y. and Li. X. J., "Reservoir stratum characteristics and geothermal resources potential of Rongcheng uplift geothermal field in Baoding, Hebei," Chinese Journal of Geology, vol. 48, no. 3, 922-931, 2013. DOI: $10.3969 /$ j.issn.0563-5020.2013.03.026.

[3] Pang Z. H., Hu S. B. and Wang J. Y., "A roadmap to geothermal energy development in China," Science\&Technology Review, vol. 30, no. 32, 18-24, 2012. DOI: $10.3981 /$ j.issn. 1000-7857. 2012.32.002.

[4] Wang J. Y., Hu. S. B and Pang Z. H., "Potential assessment of hot dry rock geothermal resource in mainland China," Science\&Technology Review, 30, no. 32, 25-31, 2012. DOI: 10.3981/j.issn.10007857.2012.32.003.

[5] Kose, R., "Geothermal energy potential for power generation in Turkey: A case study in Simav, Kutahya," Renewable and Sustainable Energy Reviews, vol. 11, no. 3, 497-511, 2007. DOI: 10.1016/j.rser.2005.03.005.

[6] Ba J. J. and Xu S. G., "The research on basic characteristics and geophysical prospecting in yiliang 
geothermal field, kunming, China," International Journal of Earth Sciences and Engineering, vol. 8, no. 6, pp. 2838-2844, 2015.

[7] Wang G. L., Zhang F. W. and Liu Z. M., "An analysis of present situation and prospects of geothermal energy development and utilization in the world," Acta Geoscientia Sinica, no. 2, pp. 134-139, 2000. DOI: 10.3321/j.issn: 1006-3021.2000.02.004.

[8] Lin W. J., Liu Z. M., Ma F., Liu C. L. and Wang G. L., "An Estimation of HDR Resources in China's Mainland," Acta Geoscientica Sinica, no. 5, pp. 807811, 2012. DOI: 10.3975/cagsb.2012.05.12.

[9] Wang J. Y., Gong Y. L. and Ma W. B., "Analysis and suggestion on the main problems of geothermal energy developed in China," Geothermal Energy, no. 1, pp. 14-17, 2011.

[10] Mongillo, M. A., "Preface to geothermics special issue on sustainable geothermal utilization," Geothermics, vol. 39, no. 4, pp. 279-282, 2010. DOI: 10.1016/j.geothermics.2010.09.011.

[11] Dotsika, E., Poutoukis. D. and Raco. B., "Fluid geochemistry of the Methana Peninsula and Loutraki Geothermal Area, Greece," Journal of Geochemical Exploration, vol. 104, no. 3, 97-104, 2010. DOI: 10.1016/j.gexplo.2010.01.001.

[12] Barbier E., "Nature and technology of geothermal energy: A review," Renewable \& Sustainable Energy Reviews, no. 01, pp. 1-69, 1997. DOI: 10.1016/S13640321(97)00001-4.

[13] Ingvar, B. F., "Geothermal energy for the benefit of the people," Renewable and Sustainable Energy Reviews, no. 3, pp. 299-312, 2001. DOI: 10.1016/S1364-0321(01)00002-8.

[14] Zuo Y. H., Qiu N. S. and Hao Q. Q., "Present Geothermal Fields of the Dongpu Sag in the Bohai Bay Basin," Acta Geologica Sinica (English Edition), no. 3, 915-930, 2014. DOI: 10.3969/j.issn.10009515.2014.03.016.

[15] Nyabeze, P. K., Venter. J. S. and Olivier, J., "Characterisation of the thermal aquifer associated with the Siloam hot spring in Limpopo," Ano. n. Proceedings of the 3rd IASTED African Conference on Water Resource Management, [S.1.]: Africa WRM, South Africa, pp. 77-82, 2010.

[16] Olivier, J., Venter, J. and Jonker. C. S., "Thermal and chemical characteristics of hot water springs in the no. rthern part of the Limpopo province, South Africa," Water SA, vol. 37, no. 4, pp. 427-436, 2011. DOI: 10.4314/wsa.v37i4.1.

[17] Edmunds, W. M., " Bath thermal waters: 400 years in the history of geochemistry and hydrology," 200 Years of British Hydrogeology, vol. 225, no. 1, pp. 193-199, 2004. DOI: 10.1144/GSL.SP.2004.225.01.12.

[18] Hellman, M. J. and Ramsey. M. S., "Analysis of hot springs and associated deposits in Yellowstone National Park using ASTER and AVIRIS remote sensing," Journal of Volcano. logy and Geothermal Research, vol. 135, no. 1-2, pp. 195-219, 2004. DOI: 10.1016/j. jvolgeores.2003.12.012.

[19] Faulds, J. E., Coolbaugh M. F. and Beno. it. D, "Structural controls of geothermal activity in the no. rthern Hot Springs Mountains, western Nevada," The tale of three geothermal systems (Brady's, Desert Peak and Desert Queen): Transactions-Geothermal Resources Council, 34, no. 2, pp. 622-630, 2010.
[20] Chandrajith, R., Barth. J. A. C. and Subasinghe. N. D, "Geochemical and isotope characterization of geothermal spring waters in Sri Lanka: Evidence for steeper than expected geothermal gradients," Journal of Hydrology, 476, no. 7, pp. 360-369, 2013. DOI: 10.1016/j.jhydrol. 2012.11.04.

[21] Chai, R., Wang. H. and Liu Y., "Application of multi mineral balance method to estimation of geothermal temperature," Coal Science and Technology, no. 4, pp. 100-103, 2010.

[22] Han, D., Zhang. X. and Jin. J., "Evaluation of groundwater hydrochemical characteristics and mixing behavior in the Daying and Qicun geothermal systems, Xinzhou Basin," Journal of Volcanology and Geothermal Research, vol. 189, no. 1-2, pp. 92-104, 2010. DOI: 10.1016/j. jvolgeores.2009.10.011.

[23] Peiffer, L., Wanner. C. and Spycher. N., "Optimized multicomponent vs. classical geothermometry: Insights from modeling studies at the Dixie Valley geothermal area," Geothermics, vol. 51, pp. 154-169, 2014. DOI: 10.1016/j.geothermics.2013.12.002.

[24] Hu J., Tu L. Q. and Liu H. P., "Geological features and formation mechanism of Tangchi Hot Spring in Jiulongshan Mountain Area," Geological Science and Technology Information, vol. 31, no. 4, pp. 86-90, 2012.

[25] Fournier, R. O., "Chemical geothermometers and mixing models for geothermal systems," Geothermics, no. 5, pp. 41-50, 1977. DOI: $\underline{10.1016 / 0375-}$ 6505(77)90007-4.

[26] Giggenbach, W. F., "Geothermal solute equilibria. Derivation of Na-K-Mg-Ca bioindicators," Geochimica et Cosmochimica Acta, vol. 52, no. 12, pp. 2749-2765, 1988. DOI: $\underline{10.1016 / 0016-}$ 7037(88)90143-3.

[27] Verma, S. P. and Santoyo. E, "New improved equations for $\mathrm{Na} / \mathrm{K}, \mathrm{Na} / \mathrm{Li}$ and $\mathrm{SiO} 2$ geothermometers by outlier detection and rejection," Journal of Volcanology and Geothermal Research, vol. 79, no. 12, 9-23, 1997. DOI: 10.1016/S0377-0273(97)00024-3.

[28] Giggenbach, W. F., "Geothermal gas equilibria," Geochimica et Cosmochimica Acta, vol. 44, no. 12, pp. 2021-2032, 1980. DOI: $\underline{10.1016 / 0016-}$ 7037(80)90200-8.

[29] Guo, Q., Wang. Y and Liu W., "Major hydrogeochemical processes in the two reservoirs of the Yangbajing geothermal field, Tibet, China," Journal of Volcano. logy and Geothermal Research, vol. 166, no. 3, pp. 255-268, 2007. DOI: 10.1016/j.jvolgeores.2007.08.004

[30] Pirlo, M. C., "Hydrogeochemistry and geothermometry of thermal groudwaters from the Bidsville Track Ridge, Great Artesian Basin, South Australia," Geothermics, vol. 33, no. 6, pp. 743-774, 2004. DOI: 10.1016/j.geothermics.2004.07.001.

[31] Yan, T. N., Science of the Drilling \& Tunneling Engineering, Wuhan: China University of Geosciences Press, pp. 151-184, 2010 (in Chinese).

[32] Liu, X. P., Zhen. X. H and Wang. Z. M, "Study of the silicate fluid for prevention of borehole-wall collapse and its application to drilling in carbonaceous mudstone," Geology and Exploration, vol. 46, no. 5, 967-971, 2010 (in Chinese with English abstract)

[33] $\mathrm{Hu}$, J. L., "Research and application of complex formation geological drilling fluid," Beijing: China University of Geosciences, pp. 1-123 (in Chinese). 
[34] Shi, D. Q., Wang. Z. M and Yan. Z. H, "Discussion and practice on wall protection in complicated formation in the Shizimiao gold field," Geology and Exploration, vol. 46, pp. 1301-1304, 2010 (in Chinese with English abstract).

[35] Chen, L. Y. and Su. N., "Application of geothermal drilling mud," Exploration Engineering (Drilling \& Tunneling), S1, pp. 244-246, 2003. (in Chinese with English abstract).
[36] Zhang, Y., "Study of salt water-based mud used for high temperature wells," Geology and Exploration, vol. 35, no. 2, pp. 61-64, 1999 (in Chinese with English abstract).

[37] Xu, S. G. and Guo. Y. S., Fundamental Geothermics, Beijing: Science Press, pp. 36-51, 2009.

[38] Wang, W. W., Flow and Heat Transfer of Fluid, Beijing: Chemical Industry Press, 2002.

[39] Zhang, X. M. and Ren. Z. P., Heat Transfer, Beijing: China Building Industry Press, 2002. 